\title{
The Research on the Construction of Campus Culture in Colleges and Universities under the Trend of Value Diversification
}

\author{
Xinjian Huang ${ }^{1}$, Xiangqin $\mathrm{Xu}^{2}$, Yu Gu${ }^{1}$ \\ ${ }^{1}$ Medical School of Jiangsu University, Zhenjiang, China \\ ${ }^{2}$ Department of medicine, Jiangsu University, Zhenjiang, China
}

Email address:

hxj141@126.com (Xinjian Huang)

To cite this article:

Xinjian Huang, Xiangqin Xu, Yu Gu. The Research on the Construction of Campus Culture in Colleges and Universities under the Trend of Value Diversification. Education Journal. Vol. 4, No. 4, 2015, pp. 170-174. doi: 10.11648/j.edu.20150404.15

\begin{abstract}
Campus culture is a sum of thinking patterns, moral standards, behavior habits and values that formed during the creation and development of colleges and universities and it eventually became a consensus among teachers and students. Excellent campus culture reflects the philosophy and features of colleges and universities and can promote common beliefs and values among massive numbers of teachers and students. College students are a generation of activeness. With the interaction, conflicts and fusion of cultures, their ideology has also become multiple, diverse and changeable. The contemporary university students' values are showing a trend of diversification. This paper analyzes the main problems and necessities of campus culture construction and discusses specific paths of campus culture construction in such a situation.
\end{abstract}

Keywords: Campus Culture, Values, Colleges and Universities

\section{Introduction}

With the rapid development of social economy as well as the deepening of the internationalization of education, ideologies and cultures of college students have also exchanged and merged and are showing a diversification of values, main features of which are: expansion of material desires, protrusion of individualism, evidence of multi-value orientation and so on. How to construct positive campus culture under current circumstances is a problem worth paying close attention to for colleges and universities.

Campus culture is a sum of thinking patterns , moral standards 、 behavior habits and values that formed during the creation and development of colleges and universities and it eventually became a consensus among teachers and students[1].It is the embodiment of the comprehensive strength of a university and an effective carrier to cultivate talents.Campus cultural environment plays an important role in subtly edifying and inspiring college students and strengthening campus culture construction will have a significant impact on students' growth. This paper analyzes the main issues and necessities of campus culture construction and discusses specific paths of campus culture construction from the four aspects of spiritual culture construction, material culture construction, system culture construction and behavior culture construction.

\section{The Main Problems Existing in College Campus Culture Construction Under the Trend of Multiple Culture}

At present, college students' multicultural values and ideologies are intertwined and have influences on each other such as the values of collectivism, economy, and different civilian beliefs and faiths ${ }^{[2]}$. Especially with the rapid spread of Internet, television, catering and other carriers, these values get to penetrate deep into the college students ${ }^{[3]}$. The confluence and interaction of various values has a direct impact on campus mainstream values, which challenges campus culture construction ${ }^{[4]}$. a survey shows: The answers to the question about "the ideological pursuit of majority Chinese people" are as following: $28.6 \%$ of college students worship money , $24.1 \%$ behave self-senterdly, $17.9 \%$ believe in egoism , $10.1 \%$ prepare to contribute to che country ${ }^{[1]}$. There are there main problems in the construction of cellege 
campus culture $\mathrm{e}^{[5]}$

\subsection{Imbalance Between Inheritance and Innovation}

Each university has its own development history. Distinctive campus cultures were rooted in and inherited from this history of development and came into being after the integration and concentration of various practical factors and innovation factors ${ }^{[6]}$. Therefore, in order to construct unique and excellent campus culture, we have to achieve a balance between inheritance and innovation. However, some colleges and universities are only interested in compiling and promoting philosophies and slogans, pursuing eye-catching effect and ignoring the foundation and tradition of the schools. As a result, cultural characteristics are diluted and cultural connotation is lost. It not only affects the positioning and development of those universities, but also affects the motivation and cohesion campus culture has to teachers and students.

\subsection{Imbalance Between Construction and Management}

The main manifestation is that campus culture construction and school management are in two tracks and do not have much integration with each other ${ }^{[7]}$. Adopting 'campaign style' to carry out theme-day activities and pursuing the short-term climax effect, schools does not make campus culture construction a part of their regular management and they lack long-term, in-depth management methods, which also makes cultural elements nowhere to be seen in their management mode and management style. This separation between cultural construction and management results in a departure between 'planning' and 'acting', making culture system just an 'exhibition' and 'decoration'. In that case, campus culture construction became difficult to achieve.

\subsection{Imbalance Between Hardware and Software}

In recent years, colleges and universities have achieved historic breakthroughs and results in hardware construction. Whether the teaching facilities, the teaching environment, or places for culture and gym activities and living, they have all got enough attention and development. However, while hardware construction is being paid full attention to, the software construction, which is the soul of campus culture, is obviously insufficient and falling behind. For instance, the spirit of culture construction is not infiltrated into the management institutions and criterions of universities. Another example is that schools do not give much thought to the mental attitudes and value orientations of teachers and students. And, communication and researches about how core values guide campus culture construction are not systematically carried out.

\section{The Necessities of Strengthening College Campus Culture Construction Under the Trend of Value Diversification Tendency}

\subsection{The Needs to Enhance the Competitiveness of Colleges and Universities}

Construction of advanced culture is a necessary part of building an advanced country and society. The current social is overall civilized, but there are also some problems and contradictions that affect social civilization, including those in colleges and universities. Thus, we must attach great importance to campus culture construction of colleges and universities and use campus culture as a carrier to spread positive energy and views so that we can make great contribution to the progress of our country and society.

Universities are the basic elements that constitute a society and play an important role in building a national culture. Harmonious campus construction must be supported by the corresponded campus culture. Campus culture should incorporate material culture including material facilities and physical environment of school teaching, scientific research and living, institutional culture including various school rules and regulations as well as spiritual culture including various institutions and pursuits for values, beliefs and faiths, moral emotions, thinking patterns, behavior standards , interpersonal relationships and so on, all of which are shared by all students, teachers and staff. Only positive school cultures will have the vitality and influence and make the universities more attractive, cohesive and competitive ${ }^{[6]}$.

\subsection{The Needs of College Students to Grow up and Become Talented}

Contemporary college students are mostly 90s generation and the only children in their families, which adds certain uniqueness to their physical and mental characteristics and laws of growth. They have shown quite new features in many aspects such as thinking patterns, value judgment, life habits, language expression, personality pursuits and so on. They grew up in the country's period of reform and opening up during which China's economic development is very good, but are faced with a much more complicated and changeable social environment than before, such as loss of political faith, the weakening of ideals and beliefs, vague value orientation, over-pursuits for material pleasure and many other social problems that can hardly be ignored. They need to deal with all kinds of unexpected challenges in the future and take the responsibility of building the nation and serving the society. This requires universities to pay attention to students' growth and improve college students' comprehensive qualities and abilities in all aspects especially in the aspect of having the right views and values. 
Therefore, we must carefully nurture college students to practice the national core values and infiltrate the core values education into every aspect of campus life to let college students understand, trust and root the values in the depths of their consciousness so that the values can gradually transform into their inner beliefs and conscious behavior ${ }^{[8]}$. Colleges and universities should make full use of culture's function of educating and inspiring people and put cultivating and practicing national core values into the whole process of campus culture construction. University departments must work together to put national core values education into teaching materials, classrooms and students' minds.

\section{The Main Paths of College Campus Culture Construction}

To construct college campus culture, colleges and universities must adhere to the four aspects of spirital culture, material culture, institutional culture, behavior culture construction simultaneously, harmoniously and uniformly ${ }^{[9]}$.

\subsection{Constructing the Spiritual Culture}

University spirits are a combination of a series of educational concepts, educational ideas and educational value pursuits that have been accumulated and precipitated in the long history of school development. They are the views on the most fundamental problems in the school, a school consciousness and cultural concept and the soul of campus culture. They include not only people's ideas, but also the refined text expression. A variety of activities people were involved in under the guidance of their concepts and the spiritual atmosphere that formed during those activities. All of the above surround the school philosophy and have become a massive and complicated aggregation, which contains the material and the spiritual, the concrete and the abstract, the conscious and the unconscious, the subjective and the objective and understanding and practice. Campus spirit culture is mainly embodied in the construction of learning style and school style. It penetrates into a variety of culture carriers and behavior bodies, making people always truly feel its unique appeal, cohesion and impact. Good campus spiritual cultures can naturally and unconsciously purify our hearts and edify us.

The essence of college spiritual culture is to be generally guided by national core values ${ }^{[10]}$. We have to put the contents and requirements of the national core values into college spiritual culture and combine these elements with various comprehensive factors such as the traditions and features of the colleges and extract and purify them to get an consensus that all teachers and students agree with and yearn for $^{[11]}$. We should also carry out the construction of campus culture under the general principles of 'guiding at macro level, infiltrating at micro level, edifying culturally and accumulating in practice' and make more specific the patriotism, collectivism, national spirit, time spirit,social honor views and so on. Firstly, we can positively promote learning theories and use the theories to encourage teachers and students to read more and read better. Secondly,we can improve the ideological levels of teachers and students via organizing contests about values and carrying out cultural discussion and communication. Thirdly, we can encourage academic researches on values in order to improve the theoretical levels of teachers and students as well as school's management and execution abilities. Last but not least, we should create a fine and harmonious interpersonal environment where all teachers and students will make integrity a cornerstone of both their life and work and develop a more tolerant, noble and pure moral personality.

\subsection{Constructing the Material Culture}

Material culture construction in campus culture is a concrete carrier of campus culture construction, which contains human culture physically. It is a general name of the embodiment of culture existing in materialized forms in the development of colleges and universities. In campus culture construction, material culture construction is a necessary precondition to accelerate campus culture construction as well as an important approach to and carrier of it. In a certain extent, the construction situation of material culture directly affects the quality and general level of campus culture.

Material culture construction includes not only visible and tangible objective existences on the campus, such as various buildings, books and reference materials, equipment for teaching and scientific researches, recreation facilities, campus network facilities and so on, but also ornamental environment layouts, such as the general plan and layout of the campus, decoration of the buildings, paths and roads of the campus, green places, sculptures and tablets and so on. Material culture with rich connotations is the material basis of college campus culture as well as an important symbol of the school's comprehensive strength, which indirectly reveals the quality and creative abilities of teachers and students. In the process of college material culture educating people, the guidance from national core values is also needed. Making core values and school spirit a firm part of campus material culture construction will reflect collective wisdom, power and spirits of the teachers and students and embody the highly concerted development of material and spiritual culture. This environment and atmosphere created by clean, elegant and civilized material culture will greatly stimulates students' desire for knowledge, accelerate positive progress of both teachers and students. As a result, the students in this environment will be educated right by the environment itself.

\subsection{Constructing the Institution Culture}

To get any value widely recognized and supported and consciously put into practice by all teachers and students, we have to embody its basic spirit in our basic institutions. In other words, the design of the institutions must reflect 
the content and spirit of the core values. We need to strengthen system management, dilute human management and retain the authority of the institution. We should make the system of rewards and penalties the carrier of campus culture by formulating scientific and complete regulations and evaluation system and improving the mechanism of coordination, interests safeguarding, responsibilities, rewards and penalties, demonstration and inspiring and restraint. By doing that, we get to encourage the advanced, push the less advanced and punish the wrong, which helps make national core values a considerable, concrete and operable realistic factor.

Institution culture construction consists of three aspects of system construction, organization construction and team construction. Organization construction and team construction are to ensure that system construction is put into practice and make it function effectively in regulating people's behaviors on the campus. The completeness, perfection and capabilities of campus culture organization play a quite important and decisive role in normally carrying out campus cultural activities and strengthening campus culture construction. We are supposed to make teachers and students gradually receive national core values education in their daily life and work and turn the outer restraint of regular management into their inner self-disciplines and qualities by putting the concept of 'culture educating people' into all aspects of the management, service and education of colleges and universities.

\subsection{Practicing the Behavior Culture}

For a person, being extraordinary should be a habit rather than a behavior; for a university, being extraordinary is not the embodiment in only one thing or for just a short while, but an atmosphere, a kind of spirit and a kind of culture. The construction of campus behavior culture is the key and goal of campus culture construction and a long-term systematic project. However, some uncivilized and disharmonious behaviors are still sometimes seen on the campus, such as being late for class, cheating in examinations, academic misconduct, not being polite, trampling on the flowers, improper words and acts on the internet, wasting food in canteens and so on. The key to making campus behavior culture a kind of belief and habit is to change our stereotype and following the guidance of national core values.

Schools should attach great importance to the brand construction of behavior culture, establish high-grade campus activities that are rich in cultural connotations and innovate the forms of activities, such as further carrying out thematic education activities in some major memorial days or on some festivals like the flag raising ceremony, keynote speeches, singing competitions. By doing those, schools get to integrate the education with the activities and enrich students' sentiments. At the same time, schools should make the overall goal of moral education specific, close to life and hierarchical so that the goal will be seen, heard, kept in minds and hearts. Schools should also make full use of blackboard newspaper, sayings, book corners, blog, QQ, We Chat and other carriers to spread advanced ideas among college students. Besides, schools should make behavior culture construction more concrete via filial piety and elegance education as well as related activities so that the behavior culture construction will be audible, speak able, readable and enjoyable. The requirements of elegance should be concrete on our mouths - fewer gossips, less nonsense and less swearing; on our hands-no scarifying, no craving disorderly and no littering; and on our legs- no disorder steps, kicks and running. By putting education like ideological and moral education and behavior criterion education into campus cultural activities which students are glad to see and participate in, schools get to strengthen their invisible education purposes with visible acts, which helps enhance the shock to students' inner experience and improve the effect of these educational activities.

Fund Project: Major project of College Students Ideological and political education, Jiangsu University 2013: Research on contemporary college students' value orientation and trend (JDXGSA201303); Teaching reform and research project, Jiangsu University 2013: College Students Party building leading the campus culture construction and interacting each orher (2013JGYB042).

\section{References}

[1] Peng Jun. Survey and analysis of campus culture and life of college students[J]. Journal of University of Science and Technology Liaoning, 2010 (12).

[2] Yunshan. Cultural consciousness ,cultural confidence and cultural self - Thinking about the prosperity and development of socialist culture with Chinese characteristics[J]. Red flag presentation, 2010(16);48.

[3] Ding Xiangyan. Analyzing on the type and basic features of social ideological trend. People's forum, 2013 (1).

[4] YangLiuxin. Values education and cultural identity in University [J]. Peking University education review, 2008, (10).

[5] Liu Qiaozhi. Inheritance, Innovation and AdvanceThinking about college campus culture construction [J].Journal of Jiaxing University, 2010(3).

[6] The Ministry of education. Comprehensively promote the legal governance implementation outline .http / / legal.china.com.cn / 2013-01/16/ Content_27706714.htm.

[7] Li Ruiqing, HuJianqiang, Luo Chunke. Study on college students culture consciously cultivation under the leading of the spirit of the party's eighteenth CPC of China [J]. History of The pary, $2013(8): 64-68$.

[8] Deng Bin,Yang Yan. Study on the whole course of the education of the socialist core values [J]. Campus Party Construction and Ideological Education, 2013(2).

[9] Huang Xinjian, Xu Xiangqin,Yao Xinyu. Research on the construction of college campus culture under the guidance of socialist core values[J].Campus party construction and ideological education, 2015(6). 
[10] Niu Yuping. Thinking of The socialist core value system leading the trend of social thoughts in Colleges and universities $(\mathrm{J})$. Journal of Liaoning Institute of administration, $2010(3)$.
[11] Zhang Lianqi, Strengthening the construction of the socialist core value system, News network of the Communist Party of China, 2008.7.7. 